\title{
Coastal Tourism Management to Support Economic Community Development in Bantul Regency, Yogyakarta, Indonesia: Problems and Solutions
}

\author{
Istiana Rahatmawati \\ University of Pembanganan Nasional "Veteran" \\ Yogyakarta \\ rahatmawati@gmail.com.
}

\author{
Sri Muryantini \\ University of Pembanganan Nasional "Veteran" \\ Yogyakarta \\ sri.muryantini@upnyk.ac.id
}

\begin{abstract}
Indonesia is the archipelago state. Indonesia comprise more than 17 thousand islands with beautiful panorama especially the magnificent of coastal tourist areas. Arief Yahya the minister of Tourism of Indonesia (2016) said Indonesia got 1 Million USD from coastal tourism or one percent of total foreign exchange. It shows that the government's policy on coastal tourism and its services sector are not yet fully implemented. Bantul regency have 13 coastal tourist areas which are not well managed yet, and four of them are not handed yet by government. This research is conducted in the field of research and library research. The aim of this research is to identify problems and offer solutions on coastal tourism management in Bantul Regency. Data were collected within observation, in-depth interview and documentation. The result of this study found that there are three main constraints in coastal tourism management, namely: (1) The synchronisation between government policy and community interests; (2) Human Resources; (3) Budget. The suggested solutions are that: (1) government should share their development programs and discuss it with the local community in order to get the support the programs. (2). The competency of human resources in the area of study is needed developing to be profesional tourist agents. (3). The tourism sector should be the first priority scale in the developmental stage. Similarly, the limited budget should be rearranged by government and the parliament.
\end{abstract}

Keywords: coastal tourism, management, economic development

\section{INTRODUCTION}

Indonesia, the archipelago state $70 \%$, comprise sea, over 1,7000 islands, which spread along the equator from 95' to 141' East Longitude (about 5000 $\mathrm{km})$ and about $2000 \mathrm{~km}$ width, from 6' North Latitude to 11 ' South Latitude. It can be said Indonesia as 'the marine continent' variations of sea depth in amount of meters to thousands meter below (Banda trough). The physical characteristics are various concerning with such as, ebb and flow, the temperature, the stream, the diverse and seabed. The beautiful scenery down the sea within the variety of sea habitants, flora and fauna, beautiful coasts, calm sea, or even big waves are big potency for marine and coastal tourism that can contribute national income significantly. However, Mr. Arief Yahya the minister of Tourism said (2016), coastal and marine tourism contribute only 1 percent foreign exchange from Indonesia's total foreign exchange [1]. The President had declared strategic location Indonesia in the cross position between Asia and Australia Continent and between Hindia and Pacific Ocean in 2014. Indonesia is the World's Maritime Pivot. The Governor of Yogyakarta Special Region then declared the New Development Paradigm (Yogyakarta Renaissance) [2], the development used from the northern part to the south with local wisdom "Dagang Layar-Among Tani". The gate of Yogyakarta Province is facing to the Hindia Ocean. The Yogyakarta south coast area become tourism economic development goals because along the beaches in southern Yogyakarta province can be developed to become the world class coastal tourism supporting by diversity and variety of cultural attraction. Bantul Regency in the southern Yogyakarta Province has 13 beaches as tourists destination, some already exist for tourism, others are in progress. As the tourism development are not managed well, the existence of these beaches does not significantly earn benefit to the local community welfare nor the nature conservation. The problems should identified and the solutions have to be offered in order to establish the development's goal.

\section{METHOD}

This research conducted as Field Research. The method of this research is descriptive qualitative. Respondents are the key persons. They are related governmental institution namely Dinas Kebudayaan (Culture Office of Bantul Regency), Dinas Pariwisata 
(Tourism Office of Bantul Regency), the members of Parliament of Bantul Regency, Community of Tourism (Kelompok Sadar Wisata), Local community informal leader, Groups of hobbies and economic activities. The data were collected direct observation, focus group discussion, in-depth interview and documentation.

\section{RESULT AND DISCUSSION}

The area of Bantul Regency is 50.685 hectares that distributed into 17 districts, but this is just 3 districts within the beach: Srandakan is 1.832 hectares $(3,61 \%)$, Sanden is 2.316 hectares $(4,57 \%)$ and Kretek is 2.677 hectares $(5,28 \%)$ [3].

Bantul has diverse and various types of tourism objects such as 38 villages tourism, culinary, nature, art and culture, sites heritage, 13 coastal touristic area and many others. Managing those potencies of tourism industry, the government Bantul regency issued some regulation such as Perda No. 3 Th 2003 (The regulation on tourism business licence) [5], Perda No. 5 Th 2005 (the establishment of culture and tourism office) [6], and Perda No.18 Th 2015 (Region tourism development master plan 20152025) [7].

\section{The Vision of Bantul Regency Tourism Development 2005-2025}

According to the condition, problems and challenges in next 20 years from 2005 and the calculation on strategic factors and the potencies of Bantul Regency, the vision of Bantul Regency Tourism Development 2005-2025 is that Bantul becomes the main tourist destination in Indonesia in the harmony of nature and culture for the community welfare (The Document of RIPPARDA Kabupaten Bantul 2005 - 2025) [7].

The Mission of Bantul Development 2005-2025 to perform the vision is designed in four Development Mission. They are:[7]

1. developing green and sustainable nature, culture and on certain purpose tourism destination based on community empowerment

Tabel 1. The Total Area by District and Villages near beach 2016

\begin{tabular}{|c|c|c|c|c|}
\hline \multirow[t]{2}{*}{ DISTRICT } & \multirow[t]{2}{*}{ VILLAGE } & \multirow{2}{*}{$\begin{array}{c}\text { AREA } \\
\text { OF } \\
\text { REGION } \\
\left(\mathrm{KM}^{2}\right)\end{array}$} & \multicolumn{2}{|c|}{$\begin{array}{c}\text { PERCENTAGE TO } \\
\text { AREA }\end{array}$} \\
\hline & & & $\begin{array}{c}\text { DIS- } \\
\text { TRICT }\end{array}$ & $\begin{array}{l}\text { REGEN } \\
\text { CY }\end{array}$ \\
\hline Srandakan & Poncosari & 11,86 & 64,74 & 2,34 \\
\hline \multirow[t]{2}{*}{ Sanden } & Gadingsari & 8,12 & 35,06 & 1,60 \\
\hline & Srigading & 7,57 & 32,69 & 1,49 \\
\hline \multirow[t]{2}{*}{ Kretek } & Tirtohargo & 3,62 & 13,52 & 0,71 \\
\hline & Parangtritis & 11,87 & 44,34 & 2,34 \\
\hline
\end{tabular}

Source: Bantul in figure, 2017 [4].
2. advancing integrated marketing, responsible and in large scale to increase the number of visitors within technology adjustment

3. developing competitive and credible tourism industries that can activate business cooperation and respond to ecological and socio-cultural sustainability

4. building up tourism institutions, effective and efficient human resources in order to perform the community awareness on tourism

RIPPARDA 2015-2015 determined three subdistricts in the southern Bantul Regency (Kretek, Sanden and Srandakan) as the nature, culture, aero sports, religious tourism area. There are 13 beaches in this three sub-districts. Nine of the beaches already exist namely: Parang Tritis, Parang Kusumo, Goa Cemara, Cemara Sewu, Barchan, Depok, Kuwaru, Samas, Pantai Baru and four of them are on-going progress namely Cangkring, Pelangi, Pandansari dan Pandansimo[8]. Besides the beaches, there are many others tourist attractions nearby, such as Water Fall in Parang endhog, Site Heritage Panepen Cave (the origin place of the name "parangtritis"), Parang Wedang hot spring sulfur water (medical tourism), fresh water swimming pools along the Parangtritis beach, Barchan Gumuk Pasir (the only one in South East Asia or one from four sand dunes in the world), Gardu Action (Out Bond area), Aero Sport area in Parang Kusumo, Mangrove Forest, Garden Flowers, Photo spots, Shrimps ponds, Stretch of rice fields, Labuhan Bekti Pertiwi Pisungsung Jaladri (annual cultural event-sea charity), Pilgrimage, Culinary (sea food etc.)

\section{Problems and Solutions on Bantul Regency: Coastal Tourism Management}

Management on coastal tourism are necessary to establish the tourism development goals. Management is a process that is used to accomplish organizational goals or to achieve what organization want to achieve (Bohoris and Vorria). Coastal tourism is a process involving tourists and the people and places they visit, particularly the coastal environment and its natural and cultural resources [9]. Most coastal tourism takes place along seashores up to shorelines.

As a matter of fact, the setting of zones and spatial areas are under policy guidance, which is not yet implemented. Therefore, there is no regulation enforced because the lands belong to the local authority 'Soultan' (Soultan Ground). There is a potential conflict in the community level and also the degradation condition on ecological aspects. Instantly, the zone regulation number 31 point 2 (pasal 31 ayat 2) that the zones for Mangrove forest are converted to shrimps ponds [10] [11]. The local informal leader Mr Suradji said that the unplanned business development along the coastal area in Bantul negatively impacts on ecosystem.. "As the investors using the Soultan Ground in doing their 
business, and they are permitted by the province government we can do nothing..." said Mr Suradal, the member of parliament of Bantul Regency [12]. "Lots of tourists facilities disappeared because of abrasion in the year 2012. Businessmen then came changes the tourist area became shrimps ponds". Concerning sustainability, while ecological conservation is on the priority for environmentalists, but for developing mentalists, economic wellbeing is the most urgent policy agenda. Among these seemingly uncompromising interests are the complementary use of sustainable economic activities and ecological conservation through coastal tourism.

Related to the budget, $\mathrm{Mr}$ Suradal was disappointed because the Bantul tourism office did not submit any budget at all to the central government. The Bantul Tourism office submit 52 billion rupiahs for tourist destination development to the province government but only get 8,25 billion in this year (2018). The retribution income from the coastal tourism is big enough but not focused on maintaining the coastal tourism location. So those areas look dirty and unkempt [12].

From FGD this study found that most coastal tourism in Bantul are built in bottom-up way. The local community take the first tourism activities such us providing/arranging certain space of beach and some attraction for their business tourism [13]. When there are many visitors - usually after two years, the government then put retribution on it. For example, in Kuwaru beach, by Mr Ponijo's hand (the leader of local fishermen) Kuwaru Beach becomes famous for tourism in 2008, the government retribution payment started in 2010 (Mr Dion, the officer of destination section in Bantul tourism office) [13]. Pandansimo is used to be a famous tourist destination, but visitors move to Pantai Baru, the newest beach near Pandansimo. Mbah Warso [14] the oldest man who lives in pandansimo said that "Pantai Baru is New Pandansimo because Old Pandansimo has been already considered negative". Pelangi Beach is in progress as the coastal tourism. Local community need to elevate their skills on tourism through: training on guiding tourists, travel agents, accompaniment and socialization on Sadar and Sapta Pesona (conscious tour and seven charms) [14]. Conscious tour in the community means the participation and community supports to encourage the realization of a good situation for the growth of tourism activities in certain places. There are two dimensions on it: (1) the community as a good host and (2) the community as guests (Tourist) [7].

Economic Development is a process that influences growth and restructures economy to enhance the economic wellbeing. Economic Development is often associated with two objectives (1) job provision, and (2) improvement of life quality [15]. Economic community development requires the synergy among stake holders [16] [17]
There are local government, academics, investors and local community. The local community in Bantul Regency coastal area have big opportunities to do business on tourism. Lots of job provision should be improved in the quality of life.

\section{CONCLUSION}

The result of this study found that there are three main constraints in coastal tourism management in Bantul Regency namely: (1) the syncronisation between government policy and community interests, (2) human resources, (3) budget. The suggested solutions are that: (1) government should share their development programs and discuss it with the local community in order to synchronize interests. (2) the competency of human resources in the area of study is needed developing to professional tourism agents. (3) The tourism sectors should be put on the priority scale in development program and the budget must be fulfilled, especially for the development of coastal tourism.

\section{REFERENCES}

[1] Irianto, Okto, et al, Melancong Ke Laut: Tata Kelola Pariwisata Maritim Indonesia, PUSHANKAM UPN "Veteran" Yogyakarta dan Deputi Bidang Koordinasi Sumberdaya Alam dan Jasa, Kementerian Koordinator Bidang Kemaritiman Republik Indonesia bekerjasama dengan Aswaja Pressindo, Yogyakarta, ISBN: 978-602-6733-22-1, page:iii. 2017

[2] Biro Perekonomian dan Sumberdaya Alam Propinsi Daerah Istimewa Yogyakarta, Daya Saing Perekonomian Wilayah Pantai Selatan, Research Result Report, unpublished. 2015

[3] Bantul in Figure, https://bantulkab.bps.go.id, download May 26, 2018.

[4] Ibid.

[5] Peraturan Daerah Kabupaten Bantul Nomor 3 Tahun 2003 Tentang Perizinan Usaha Jasa Pariwisata Kabupaten Bantul.

[6] Peraturan Daerah Kabupaten Bantul Nomor 5 Tahun 2003 Tentang Pembentukan Dinas kebudayaan dan Pariwisata Kabupaten Bantul.

[7] Peraturan Daerah Kabupaten Bantul Nomor 18 Tahun 2015 Tentang Rencana Induk Pembangunan Kepariwisataan Daerah Tahun 2015-2025.

[8] Muryantini, Sri., "Peran Pemerintah Dalam Pengelolaaan dan Kesejahteraan Masyarakat di Kawasan Pesisir Yogyakarta, Pushankam dan Asisten Jasa kemaritiman", Deputi Bidang Koordinasi Sumberdaya Alam dan Jasa, Kementerian Koordinator Bidang Kemaritiman Republik Indonesia bekerjasama dengan Aswaja Pressindo, ISBN: 978-6026733-22-1. 2017 
[9] Marc, Miller L., Jan Auyong, Nina. P Hadly, Sustainable Coastal Tourism: Challenges for Management, Planning, and Eduction, Page:3, nsgl.gso.uri.edu/washu/washuw99003/1-

Introduction_Miller.pdf, download May 26, 2018.

[10] Bappeda Propinsi Daerah Istimewa Yogyakarta, Rencana Aksi Pengembangan Wilayah Pantai Selatan, Research Result Report, unpublished. 2016

[11] Sugandini., Dyah , Rahatmawati., Istiana, and Ajeng, Environmental Attitude on the Adoption Decision Mangrove Conservation: an Empirical Study on Communities in Yogyakarta, Indonesia , Paper on International Seminar in Osaka, Japan, 6-7 July 2016, SIBReseach.org/riber-7-S1.html. 2016

[12] Deepth interview with Mr. Suradal, a member of parliament of Bantul Regency, May 29, at his house in Bantul. 2018

[13] FGD with Bantul Tourism Officer at Bantul Tourism Office, April 20, 2018.
[14] FGD with people on Kuwaru and Pandasimo, April 21, 2018.

[15] Departement for Communities and Local Government, Community Economic Development, Departement for Communities and Local Government, Lawrence Weston, UK, Page:2. 2017

[16] Rahatmawati, Istiana, Paper on International Conference: The Potency of Karst Geotourism to Support Local Community's Economic Development in Gunung Kendil, Ponjong District, Gunung Kidul Regency, Yogyakarta Province, Indonesia, presented in Guilin, China. http//eprints.upnyk.ac.id/11449 ISBN:978-602-1107-06-5. 2013

[17] Wahyuni, Purbudi and Rahatmawati, Istiana, Community Development: From Destroyer to Manager (Study in Breecia Cliff, Berbah, Sleman, Yogyakarta Special Region, Indonesia), Paper on Geoheritage Conference, in Khon Kaen, Thailand, 2-6 April, 2018. 